\title{
Screening of novel 2-4 methylphenylimino-3-carboxamide substituted thiophene compound for central analgesic activity
}

\author{
Nishitha Ganugapeta ${ }^{1 *}$, Sai Sravan Kumar Reddythala ${ }^{2}$
}

\author{
${ }^{1}$ Department of Pharmacology, PESIMSR, Kuppam, Andhra Pradesh, India \\ ${ }^{2}$ Department of Community Medicine, PESIMSR, Kuppam, Andhra Pradesh, India
}

Received: 11 February 2021

Revised: 18 February 2021

Accepted: 18 February 2021

\section{*Correspondence:}

Dr. Nishitha Ganugapeta,

Email: drnishithasai@gmail.com

Copyright: ( $\subseteq$ the author(s), publisher and licensee Medip Academy. This is an open-access article distributed under the terms of the Creative Commons Attribution Non-Commercial License, which permits unrestricted non-commercial use, distribution, and reproduction in any medium, provided the original work is properly cited.

\begin{abstract}
Background: Pain is an unpleasant sensation that can range from mild, localized discomfort to agony. The mechanism of pain perception involves dedicated subsets of peripheral and central neurons. For management of pain, currently, available treatment regimens are opioid analgesics and NSAIDs which are easily available over the counter drugs. Long term use of analgesics can lead to significant impact on human renal system, cardiovascular system and analgesic abuse etc. So, there is a need for novel, safe and cost-effective analgesic compound. Hence a study on 2-4 methylphenylimino3-carboxamide substituted thiophene compound, a novel thiophene compound has been carried out in different experimental animal models.

Methods: Two methods were used to evaluate the central analgesic activity of 2-4 methylphenylimino-3-carboxamide substituted thiophene compound. First method was Eddy's hot plate method and compared to standard central analgesic, morphine. Second method was early phase of formalin induced paw licking in mice and compared to a standard drug, aspirin.

Results: With eddy's hot plate method, $40 \mathrm{mg} / \mathrm{kg}$ dose of 2-4 methylphenylimino-3-carboxamide substituted thiophene compound has shown maximum pain inhibition percentage (PIP) of $45 \%$ at 60 min compared to $125 \%$ by morphine. Whereas with early phase of formalin test, $40 \mathrm{mg} / \mathrm{kg}$ dose of 2-4 methylphenylimino-3-carboxamide substituted thiophene compound has shown maximum PIP of $44 \%$ in early phase compared to $60 \%$ by aspirin. The results were statistically significant with $\mathrm{p}<0.05$.

Conclusions: It can be concluded that 2-4 methylphenylimino-3-carboxamide substituted thiophene compound found to have minimal central analgesic activity as evident in eddy's hot plate and early phase of formalin tests.
\end{abstract}

Keywords: Analgesic, Eddy's hot plate, Formalin test, Thiophene, 2-4 methylphenylimino-3-carboxamide substituted thiophene compound

\section{INTRODUCTION}

Pain is an unpleasant sensation which ranges from mild, localized discomfort to agony. ${ }^{1}$ The mechanism of pain perception involves dedicated subsets of peripheral and central neurons. ${ }^{2}$ There are different types of pain which were differentiated qualitatively such as burning pain, pricking pain, throbbing pain, stinging pain, dull or aching pain. Pain is defined as a perception created by the brain in response to input from receptors i.e., nociceptive, visual, proprioceptive, tactile and, the internal beliefs and emotions drawn from past learning. ${ }^{3}$ It is influenced by the state of the nervous system from past and present experiences i.e. neuroplasticity, sensitivity, and associated with the priming of motor responses i.e. activity in anterior cingulate cortex and primary motor cortex and a 
heightened vigilance to the affected part of the virtual body. ${ }^{4}$ Common clinical conditions associated with pain are headache, low backache, body pain, joint pains. It is a chief complaint in $52.2 \%$ of patient visits in emergency medical care. ${ }^{5}$ Pain can be classified as acute pain and chronic pain. Acute pain usually has an identifiable temporal and causal relationship to injury or disease and is generally defined as pain of recent onset and with probable limited duration. Chronic pain usually would not be associated with any clear identifiable cause and it generally persists beyond the time of healing of an injury. Incident pain which occurs when the person moves or is moved by someone else; or may have unknown cause. ${ }^{6,7}$ Analgesic substances, such as aspirin and morphine, that interact with the transmitters and modulators of the pain system are helpful for many people with pain, but there is a great need for the development of better drugs for the alleviation and control of both acute (immediate) and chronic (long-term, pathological) pain. ${ }^{8}$ Long term use of available analgesics cause disturbances in the body system. Opioids cause multiple adverse effects involving respiratory system, central nervous system, gastrointestinal system such as sedation, mental clouding, blurring of vision, respiratory depression, constipation and urinary retention. NSAIDs cause adverse effects involving several systems of the body such as gastrointestinal tract, kidneys, central nervous system, cardiovascular system, blood and skin. A search for new, safe and cost-effective analgesic continues. A study on 2-4 methylphenylimino3-carboxamide substituted thiophene compound has been carried out. The parent compound has been studied and shows predominant analgesic activity at 15 to $30 \mathrm{mg} / \mathrm{kg} .{ }^{9}$

\section{METHODS}

Currently in this study, central analgesic activity of test compound was evaluated using two experimental animal models. First one is Eddy's hot plate method and the second method is early phase of formalin induced paw licking in mice. The study was conducted in the animal house affiliated to the people's education society institute of medical sciences and research (PESIMSR), Kuppam, Chittoor district, Andhra Pradesh after obtaining approval from the institutional animal ethics committee (No: PES IMSR/Pharma/IAEC/12/2012-13). All the animals were handled with gentle care as per the CPCSEA guidelines.

\section{Test compound}

2-4 methyl phenylimino-3-carboxamide substituted thiophene compound. Thiophene is a five-membered heterocyclic compound having Sulphur as the heteroatom. Over the past few years, research groups have conducted a comprehensive program me towards the synthesis of thiophene and their fused derivatives which have reported to possess wide range of activity. It has been reported that the parent compound, Thiophene and its derivatives possess analgesic, anti-inflammatory, local anesthetic, antimicrobial, and antifungal activities. ${ }^{1-14}$ In view of these findings, another novel synthesized derivative of thiophene namely 2-(4-methylphenylimino)-n-(2chlorophenyl)-5-isopropyl-4-methyl thiophene-3carboxamide substituted thiophene was undertaken in the present study to evaluate the analgesic activity. It was synthesized in the P.E.S college of pharmacy, Bangalore and obtained by their kind courtesy.

\section{Details of experimental animals used}

The current study was carried out in healthy male Swiss albino mice (Mus musculus) weighing between 20 to $25 \mathrm{~g}$ as they are the most widely used strain for assay of analgesics. ${ }^{15}$ Female mice were excluded to avoid the effect of estrous cycle. Also, the diseased mice and male mice weighing $<20$ and $>25 \mathrm{~g}$ were also excluded. All the mice were in propylene cages in 12:12 hours light: dark cycle, under standard laboratory conditions and water was provided ad libitum. All the mice were kept in fasting state 12 hours prior to the conduction of experiment.

\section{Eddy's hot plate method}

This experiment has been performed to verify the central analgesic activity of 2-4methylphenylimino-3carboxamide substituted thiophene compound. The paws of mice are very sensitive to heat at temperatures which are not damaging the skin. If the test compound has centrally active analgesic activity, then post administration, the time to respond to painful response such as jumping or licking of the paw will be prolonged. ${ }^{16,17}$

\section{Animals}

A total of 30 male Swiss albino mice were considered for this study. The mice which have responded within 5 seconds were included in the study. ${ }^{18}$

\section{Drugs and reagents}

The test compound 2-4methylphenylimino-3-carboxamide substituted thiophene compound cannot be dissolved in water hence, drug suspending agent $10 \%$ tween- 80 or polysorbate-80 (Merck specialties private limited, Mumbai), was used. The standard drug utilized in this experiment was Morphine, which was administered intraperitoneally using tuberculin syringe, whereas the test compound, 2-4 methylphenylimino-3-carboxamide substituted thiophene compound was administered orally using gavage.

Five groups of mice were created, and all the mice were selected randomly. Each group contains six mice. Group I received $0.5 \mathrm{ml}$ of tween- 80 per oral which was considered as control group. Group II received morphine-5 mg/kg intraperitoneally which was considered as standard group. groups III, IV and $\mathrm{V}$ received the test drug 2-4 methylphenylimino-3-carboxamide substituted thiophene compound per orally at $10,20,40 \mathrm{mg} / \mathrm{kg}$ respectively and 
all these three groups were considered as test groups. All the grouping details were mentioned below in Table 1 .

Table 1: Classification of mice into the groups in Eddy's hot plate method.

\begin{tabular}{|lll|}
\hline Group & Drug & Dose \\
\hline II & Control (10\% Tween-80) & $0.5 \mathrm{ml} \mathrm{PO}$ \\
\hline III & $\begin{array}{l}\text { 2-4methylphenylimino-3- } \\
\text { carboxamide substituted } \\
\text { thiophene compound }\end{array}$ & $\begin{array}{l}10 \\
\mathrm{mg} / \mathrm{kg} / \mathrm{PO} / \mathrm{I}\end{array}$ \\
\hline IV & $\begin{array}{l}\text { 2-4methylphenylimino-3- } \\
\text { carboxamide substituted } \\
\text { thiophene compound }\end{array}$ & $\begin{array}{l}20 \\
\mathrm{mg} / \mathrm{kg} / \mathrm{PO}\end{array}$ \\
\hline V & $\begin{array}{l}\text { 2-4methylphenylimino-3- } \\
\text { carboxamide substituted } \\
\text { thiophene compound }\end{array}$ & $\begin{array}{l}40 \\
\mathrm{mg} / \mathrm{kg} / \mathrm{PO}\end{array}$ \\
\hline
\end{tabular}

Eddy's hotplate instrument is utilized for evaluating analgesic activity of any novel compound and it consists of an electrically heated copper or glass plate surface, the temperature of which can be maintained between $55-56^{\circ} \mathrm{C}$ to evoke thermal stimulus. Using stopwatch, time for response such as jumping or licking of the paw was recorded. Mice were placed on the Eddy's hotplate. Mice which have responded with in 5 seconds were included in the study Mice with reaction time $>5$ seconds were excluded. The cut-off time, 15 seconds was considered to avoid paw damage. ${ }^{19,20}$

\section{Formalin induced paw licking in mice-only early phase}

Early phase of Formalin induced paw licking method has been evaluated for central analgesic activity of 2-4 methylphenylimino-3-carboxamide substituted thiophene compound. $0.05 \mathrm{ml}$ of $10 \%$ formalin is injected into the dorsal portion of front paw of rats. Test drug is administered \& each individual rat is placed in clear plastic cage for observation. Readings are taken at $30 \& 60 \mathrm{~min}$ and scored according to pain scale. Pain responses are indicated by elevation or favoring of the paw, or excessive licking or biting of the paw. Analgesic response or protection is indicated if both paws are resting on the floor. Effective doses can be calculated.

\section{Animals}

A total of 30 male Swiss albino mice were included for this study. 30 male mice (20-25 g) divided into 5 groups consisting of 6 animals in each group were randomly grouped as follows.

\section{Drugs and reagents}

$10 \%$ Tween- 80 or Polysorbate- 80 was used as a drug suspending agent, whereas Aspirin was used as a standard drug and 2-4 methylphenylimino-3-carboxamide substituted thiophene compound as test compound. ${ }^{21,22}$ All drugs were administered orally using gavage. The procedure was done as per the standard method suggested by Murray and Hunskaar et al. ${ }^{23}$

Five groups of mice were created, and all the mice were selected randomly. Each group contains six mice. Group I received $0.5 \mathrm{ml}$ of tween- 80 per oral which was considered as control group. Group II received aspirin per orally at the dose of $100 \mathrm{mg} / \mathrm{kg} / \mathrm{PO} / 0.5 \mathrm{ml}$ which was considered as standard group. ${ }^{24}$ Groups III, IV and V received the test drug 2-4 methylphenylimino-3-carboxamide substituted thiophene compound per orally at 10,20 and $40 \mathrm{mg} / \mathrm{kg}$ respectively and all these three groups were considered as test groups. All the grouping details were mentioned below in Table 2.

Table 2: Classification of mice into the groups in formalin test.

\begin{tabular}{|c|c|c|}
\hline Group & Drug & Dose \\
\hline I & $\begin{array}{l}\text { Control (10\% } \\
\text { Tween-80) }\end{array}$ & $0.5 \mathrm{ml} \mathrm{PO}$ \\
\hline II & Aspirin & $\begin{array}{l}100 \\
\mathrm{mg} / \mathrm{kg} / \mathrm{PO} / 0.5 \\
\mathrm{ml}^{24}\end{array}$ \\
\hline III & $\begin{array}{l}\text { 2-4 } \\
\text { methylphenylimino- } \\
\text { 3-carboxamide } \\
\text { substituted thiophene } \\
\text { compound }\end{array}$ & 10 mg/kg/PO \\
\hline IV & $\begin{array}{l}\text { 2- } \\
\text { 4methylphenylimino- } \\
\text { 3-carboxamide } \\
\text { substituted thiophene } \\
\text { compound }\end{array}$ & $20 \mathrm{mg} / \mathrm{kg} / \mathrm{PO}$ \\
\hline $\mathbf{V}$ & $\begin{array}{l}\text { 2- } \\
\text { 4methylphenylimino- } \\
\text { 3-carboxamide } \\
\text { substituted thiophene } \\
\text { compound }\end{array}$ & 40 mg/kg/PO \\
\hline
\end{tabular}

\section{Procedure}

Drugs were administered orally with the respective drugs. After 1 hour, $0.02 \mathrm{ml}$ of $5 \%$ formalin is injected into the dorsum region of hind paw of mice. Pain response is indicated by the paw licking or biting of the paw. Number of paws lickings was recorded in early phase of 0-5 min. ${ }^{25}$ Analgesic response or protection was indicated if both paws were resting on the floor with no obvious favoring of the injected paw.

\section{Evaluation}

Pain inhibition percentage was calculated using the formula: 
$\mathrm{PIP}=[$ No. of licks (control-treated group)/No. of licks in control]x100

\section{Statistical analysis}

All the continuous variables in this experiment were expressed as mean and standard deviation. Between group analyses was done with one-way ANOVA, followed by Dunnett post hoc test. Within group analyses was done with Repeated measure ANOVA test. All statistical calculations were performed using the software SPSS (statistical package for social service) for windows version 19.0. For statistical significance, two tailed probability $<0.05$ is considered.

\section{RESULTS}

\section{Eddy's hot plate method}

Pain inhibition percentage (PIP) was calculated by comparing the mean latency values before and after the administration of drug. The latency time periods i.e., the time taken by the mice to respond after placing over the hotplate, were recorded at 0, 20,60 and 90 min following the drug administration and PIP were explained below in tables and graph-1.

\section{The standard (morphine-5 mg/kg/) group of mice}

Morphine has shown mean latency time of $3.68 \pm 0.08 \mathrm{sec}$ at $0 \mathrm{~min}, 6.83 \pm 0.82 \mathrm{sec}$ at $20 \mathrm{~min}, 8.52 \pm 0.46 \mathrm{sec}$ at $60 \mathrm{~min}$ and $7.48 \pm 0.47 \mathrm{sec}$ at $90 \mathrm{~min}$ following the drug administration. Morphine has shown PIP of 80.33 at 20 min 125.04 at $60 \mathrm{~min}$ and 93.88 at $90 \mathrm{~min}$ when compared to $0 \mathrm{~min}$ following the drug administration explained below in Table 3.

Table 3: Mean latency time and PIP produced by morphine in Eddy's hot plate method in mice.

\begin{tabular}{|llll}
$\begin{array}{l}\text { Recording } \\
\text { time (min) }\end{array}$ & $\begin{array}{l}\text { Mean } \\
\text { latency } \\
\text { time } \pm \text { SD }\end{array}$ & $\begin{array}{l}\text { PIP } \\
(\%)\end{array}$ & P value \\
\hline $\mathbf{0}$ & $3.68 \pm 0.08$ & ---- & ---- \\
\hline $\mathbf{2 0}$ & $6.83 \pm 0.82$ & 80.33 & $<0.001$ \\
$\mathbf{6 0}$ & $8.52 \pm 0.46$ & 125.04 & $<0.0001$ \\
\hline $\mathbf{9 0}$ & $7.48 \pm 0.47$ & 93.88 & $<0.0001$ \\
\hline
\end{tabular}

\section{The test compound-10 $\mathrm{mg} / \mathrm{kg}$ group of mice}

Test compound of $10 \mathrm{mg} / \mathrm{kg}$ has shown mean latency time of $3.42 \pm 0.06 \mathrm{sec}$ at $0 \mathrm{~min}, 3.63 \pm 0.32 \mathrm{sec}$ at $20 \mathrm{~min}$, $4.30 \pm 0.30 \mathrm{sec}$ at $60 \mathrm{~min}$ and $3.72 \pm 0.03 \mathrm{sec}$ at $90 \mathrm{~min}$ following the drug administration. It has shown PIP of 8.61 at $20 \mathrm{~min}, 26.84$ at $60 \mathrm{~min}$ and 8.12 at $90 \mathrm{~min}$ when compared to $0 \mathrm{~min}$ following the drug administration explained in below Table 4.
Table 4: Mean latency time and PIP produced by test compound of $10 \mathrm{mg} / \mathrm{kg}$ in Eddy's hot plate method in mice.

\begin{tabular}{|llll|}
$\begin{array}{l}\text { Recording } \\
\text { time }(\text { min) }\end{array}$ & $\begin{array}{l}\text { Mean latency } \\
\text { time }\end{array}$ & $\begin{array}{l}\text { PIP } \\
(\%)\end{array}$ & P value \\
\hline $\mathbf{0}$ & $3.42 \pm 0.06$ & ---- & ---- \\
\hline $\mathbf{2 0}$ & $3.63 \pm 0.32$ & 8.61 & $<0.0001$ \\
\hline $\mathbf{6 0}$ & $4.30 \pm 0.30$ & 26.84 & $<0.0001$ \\
\hline $\mathbf{9}$ & $3.72 \pm 0.03$ & 8.12 & $<0.0001$ \\
\hline
\end{tabular}

\section{The test compound-20 $\mathrm{mg} / \mathrm{kg}$ group of mice}

Test compound $20 \mathrm{mg} / \mathrm{kg}$ has shown mean latency time of $3.22 \pm 0.16 \mathrm{sec}$ at $0 \mathrm{~min}, 3.42 \pm 0.13 \mathrm{sec}$ at $20 \mathrm{~min}, 4.33 \pm 0.21$ $\mathrm{sec}$ at $60 \mathrm{~min}$ and $4 \pm 0.11 \mathrm{sec}$ at $90 \mathrm{~min}$ following the drug administration. The test group of mice (test compound-20 $\mathrm{mg} / \mathrm{kg} / \mathrm{PO}$ ) has shown PIP of 9.02 at $20 \mathrm{~min}, 31.43$ at 60 min and 22.29 at $90 \mathrm{~min}$ when compared to $0 \mathrm{~min}$ following the drug administration explained in Table 5 below.

Table 5: Mean latency time and PIP produced by test compound of $20 \mathrm{mg} / \mathrm{kg}$ in Eddy's hot plate method in mice.

\begin{tabular}{llll}
$\begin{array}{l}\text { Recording } \\
\text { time (min) }\end{array}$ & $\begin{array}{l}\text { Mean } \\
\text { latency time }\end{array}$ & PIP $(\%)$ & $\begin{array}{l}\text { P } \\
\text { value }\end{array}$ \\
\hline $\mathbf{0}$ & $3.22 \pm 0.16$ & ---- & ---- \\
\hline $\mathbf{2 0}$ & $3.42 \pm 0.13$ & 9.02 & $<0.001$ \\
\hline $\mathbf{6 0}$ & $4.33 \pm 0.21$ & 31.43 & $<0.001$ \\
\hline $\mathbf{9 0}$ & $4 \pm 0.11$ & 22.29 & $<0.001$ \\
\hline $\mathbf{9 0}$ & & &
\end{tabular}

The test drug (test compound-40 mg/kg) group of mice

Test compound $40 \mathrm{mg} / \mathrm{kg}$ has shown mean latency time of $3.21 \pm 0.21 \mathrm{sec}$ at $0 \mathrm{~min}, 4.21 \pm 0.48 \mathrm{sec}$ at $20 \mathrm{~min}, 4.55 \pm 0.43$ $\mathrm{sec}$ at $60 \mathrm{~min}$ and $4.28 \pm 0.51 \mathrm{sec}$ at $90 \mathrm{~min}$ following drug administration. It has shown PIP of 32.38 at $20 \mathrm{~min}, 45.13$ at $60 \mathrm{~min}$ and 33.72 at $90 \mathrm{~min}$ when compared to $0 \mathrm{~min}$ following the drug administration explained in Table 6.

Table 6: Mean latency time and PIP produced by test compound of $40 \mathrm{mg} / \mathrm{kg}$ in Eddy's hot plate method in mice.

\begin{tabular}{llll}
$\begin{array}{l}\text { Recording } \\
\text { time }\end{array}$ & $\begin{array}{l}\text { Mean latency } \\
\text { time }\end{array}$ & $\begin{array}{l}\text { PIP } \\
(\%)\end{array}$ & P value \\
\hline $\mathbf{0}$ & $3.21 \pm 0.21$ & ---- & ---- \\
\hline $\mathbf{2 0}$ & $4.21 \pm 0.48$ & 32.38 & $<0.0001$ \\
\hline $\mathbf{6 0}$ & $4.55 \pm 0.43$ & 45.13 & $<0.0001$ \\
\hline $\mathbf{9 0}$ & $4.28 \pm 0.51$ & 33.72 & $<0.0001$ \\
\hline
\end{tabular}

The Figure 1 presented compared the mean latency time and PIP produced by morphine and various doses of test compound at 20, 60, 90 min with Eddy's hot plate method in mice. 


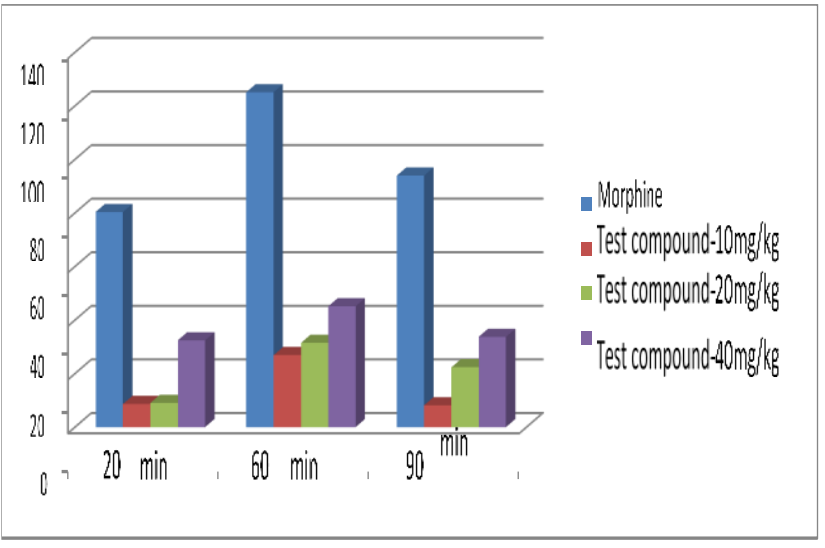

Figure 1: Mean latency time and pain inhibition percentage (PIP) produced by morphine, test drug (test compound-10, 20, $40 \mathrm{mg} / \mathrm{kg}$ ) group at $0,20,60$ and 90 min in Eddy's hotplate method in mice.

\section{Formalin induced paw licking in mice}

\section{Number of paw licks}

Central analgesic activity of test compound was determined by the early phase. Number of paw lickings were recorded in early phase of 0-5 mi. Pain inhibition percentage was calculated by comparing the drug treated values to that of control group. The PIP produced by the aspirin $(100 \mathrm{mg} / \mathrm{kg})$ is 60.11 whereas PIP values produced by the test compound i.e., 2-4 methylphenylimino-3carboxamide substituted thiophene are 12.86, 28.61 and 44.41 at doses of 10,20 and $40 \mathrm{mg} / \mathrm{kg}$ respectively. This observation indicates that the maximum PIP is produced by $40 \mathrm{mg} / \mathrm{kg}$ dose of test compound, however the activity is lesser compared to aspirin. Mean no. of paw licks and PIP produced in early phase of formalin test (Tables 7).

Table 7: Mean no. of paw licks and PIP produced by control, aspirin $(100 \mathrm{mg} / \mathrm{kg})$ and test compound at 10 , 20 and $40 \mathrm{mg} / \mathrm{kg}$ in early phase of formalin induced paw licking in mice.

\begin{tabular}{|c|c|c|c|}
\hline Group $(n=6)$ & $\begin{array}{l}\text { Mean No. of } \\
\text { licks } \pm \text { SD }\end{array}$ & $\begin{array}{l}\text { PIP } \\
(\%)\end{array}$ & $\begin{array}{l}\mathbf{P} \\
\text { value }\end{array}$ \\
\hline $\begin{array}{l}\text { Control }(10 \% \\
\text { tween-80) }\end{array}$ & $63.5 \pm 2.66$ & ----- & ---- \\
\hline $\begin{array}{l}\text { Aspirin (100 } \\
\text { mg/kg/PO) }\end{array}$ & $25.33 \pm 1.75$ & 60.11 & $<0.01$ \\
\hline $\begin{array}{l}\text { Test } \\
\text { compound (10 } \\
\text { mg/kg/PO) }\end{array}$ & $55.33 \pm 2.16$ & 12.86 & $<0.01$ \\
\hline $\begin{array}{l}\text { Test } \\
\text { compound ( } 20 \\
\text { mg/kg/PO) }\end{array}$ & $45.33 \pm 2.16$ & 28.61 & $<0.001$ \\
\hline $\begin{array}{l}\text { Test } \\
\text { compound ( } 40 \\
\text { mg/kg/PO) }\end{array}$ & $35.33 \pm 2.16$ & 44.41 & $<0.001$ \\
\hline
\end{tabular}

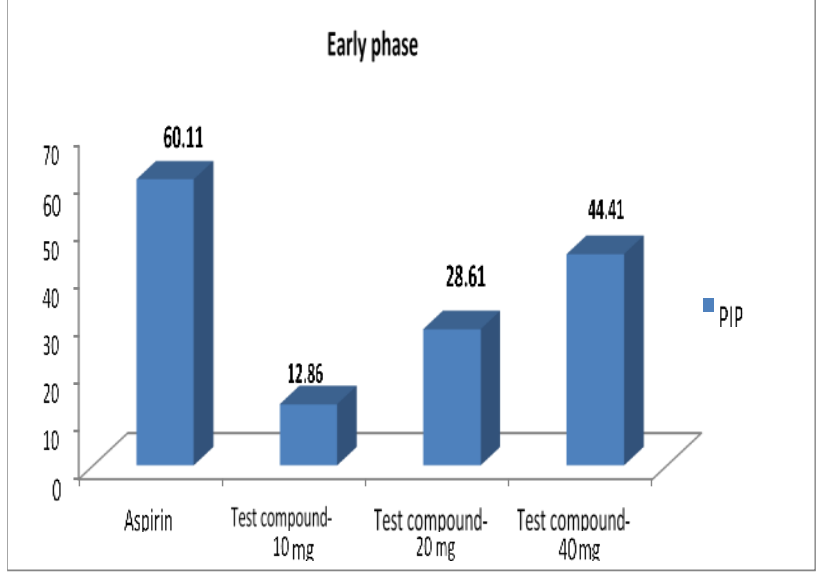

Figure 2: Bar diagram of the PIP shown by aspirin $(100 \mathrm{mg} / \mathrm{kg})$ and test drug at 10, 20 and $40 \mathrm{mg} / \mathrm{kg}$ in early phase of formalin induced paw licking in mice.

\section{DISCUSSION}

In Eddy's hot plate method, the PIP produced by the morphine $(5 \mathrm{mg} / \mathrm{kg} / \mathrm{IP})$ group of mice are $80.33,125.04$, 93.88 at 20,60 and 90 min respectively which indicates that maximum action is seen at $60 \mathrm{~min}$. The PIP produced by test compound i.e., 2-4 methylphenylimino-3carboxamide substituted thiophene are $8.61,26.84,8.12$ by $10 \mathrm{mg} / \mathrm{kg}$ dose group, $9.02,31.43,22.29$ by $20 \mathrm{mg} / \mathrm{kg}$ dose group and $32.38,45.13,33.72$ by $40 \mathrm{mg} / \mathrm{kg}$ dose group of mice at 20,60 and 90 min respectively. This indicates that the maximum action of test compound is shown by 40 $\mathrm{mg} / \mathrm{kg}$ dose at $60 \mathrm{~min}$ which is far less than that of morphine $(5 \mathrm{mg} / \mathrm{kg})$. The study infers that 2-4 methylphenylimino-3-carboxamide substituted thiophene compound has maximum central analgesic activity at 40 $\mathrm{mg} / \mathrm{kg}$ at $60 \mathrm{~min}$ which is lesser than that of Morphine (5 $\mathrm{mg} / \mathrm{kg}$ ). The maximum PIP produced by test compound is 45.13\% in Eddy's hot plate method.

In early phase of formalin induced paw licking mice, the PIP produced by the aspirin $(100 \mathrm{mg} / \mathrm{kg})$ is 60.11 whereas PIP values produced by the test compound i.e., 2-4 methylphenylimino-3-carboxamide substituted thiophene are 12.86, 28.61 and 44.41 at the doses of 10, 20 and 40 $\mathrm{mg} / \mathrm{kg}$ respectively. This observation indicates that the maximum PIP is produced by $40 \mathrm{mg} / \mathrm{kg}$ dose of test compound, however the activity is lesser compared to aspirin.

Surendra et all evaluated analgesic activity of $40 \mathrm{mg} / \mathrm{kg}$ dose of 2-chlorothiophene in mice using Eddy's hot plate method and had showed maximum central analgesic activity of $46.15 \%$ at $60 \mathrm{~min}$ when compared to $45.13 \%$ at $60 \mathrm{~min}$ by $40 \mathrm{mg} / \mathrm{kg}$ dose of 2-4 methylphenylimino-3carboxamide substituted thiophene compound which is lesser compared to 2-chlorothiophene..26,27 The same authors also concluded that with early phase of formalin induced paw licking, $20 \mathrm{mg} / \mathrm{kg}$ dose of 2-chlorothiophene has shown analgesic activity of $22.91 \%$ compared to 28.61 
by $20 \mathrm{mg} / \mathrm{kg}$ dose $2-4$ methylphenylimino-3-carboxamide substituted thiophene compound which is higher than 2chlorothiophene which infers that test compound 2-4 methylphenylimino-3-carboxamide substituted thiophene compound has central analgesic activity evaluated in the current study.

The drug can't be claimed for central analgesic activity as the maximum PIP is $<50 \%$ in Eddy's hot plate method. Under Eddy's hot plate method, all drugs have shown peak activity at $60 \mathrm{~min}$ and declined activity at $90 \mathrm{~min}$. If the study period had been continued, then the complete time course of action for all the drugs could have been recorded. Further investigation can throw light on the minimum effective dose and ceiling doses of all the drugs.

This study is a simple screening test for the presence or absence of analgesic activity for 2-4 methylphenylimino3-carboxamide substituted thiophene compound. The purpose of the study is served by demonstrating the analgesic activity in the doses employed. These results can't be interpolated for human.

\section{CONCLUSION}

The study was undertaken for screening of the synthetic compound 2-4 methylphenylimino-3-carboxamide substituted thiophene compound for analgesic activity. It has shown maximum central analgesic activity $(<50 \%)$ at $40 \mathrm{mg} / \mathrm{kg}$ dose in Eddy's hotplate method which cannot be interpreted as having significant central analgesic activity when compared to morphine $(5 \mathrm{mg} / \mathrm{kg})$. From this study, it can be concluded that the test drug, 2-4 methylphenylimino-3 carboxamide substituted thiophene compound has central analgesic action at $40 \mathrm{mg} / \mathrm{kg}$ dose in mice to a lesser extent. Further studies may be conducted in a greater number of animal species models to evaluate and confirm the findings.

\section{Funding: No funding sources}

Conflict of interest: None declared

Ethical approval: The study was approved by the Institutional Ethics Committee

\section{REFERENCES}

1. Shiel JR W. Definition of Pain. MedicineNet. 2021. Available from: https://www.medicinenet.com/pain/definition.htm. Accessed on 26 January 2021

2. Craig AD. How do you feel? Interoception: the sense of the physiological condition of the body. Nature Reviews. Neuroscience. 2002;3:655-66.

3. Breivik H, Borchgrevink PC, Allen SM, Rosseland LA, Romundstad L, Breivik H. Assessment of pain. British J Anaesthesia. 2008;101(1):17-24.

4. Turk DC, Dworkin RH. What should be the core outcomes in chronic pain Clinical trials? Arthritis Res Ther. 2004; 6(4):151-4.
5. Cordell WH, Keene KK, Giles BK, Jones JB, Jones $\mathrm{JH}$, Brizendine EJ. The high prevalence of pain in emergency medical care. Am J Emerg Med. 2002;20(3):165-9.

6. Shipton EA, Tait B. Flagging the pain: preventing the burden of chronic pain by identifying and treating risk factors in acute pain. Eur $j$ anaesthesiol. 2005;22;6:405-12.

7. Smith AK, Irena SC, Sara K, Kathllen AP, Eric W, Brie AW. The epidemiology of pain during the last 2 years of life. Ann Intern Med. 2010;153(9):563-9.

8. Rang HP, Dale MM, Ritter JM, Flower RJ. Chemical transmission and drug action in the central nervous system-Analgesic drugs; Rang and Dale's Pharmacology, Churchill Livingstone. 2007;7:442.

9. Wagnat WW, Omar MEAS, Gamal A. E. Screening for antidepressant, sedative and analgesic activities of novel fused thiophene derivatives. ACTA macuetica. 2008;58:1-14.

10. Naomi I, Matthew D. Why it hurts to be left out-The neurocognitive overlap between physical and social pain; Williams_RT424X_C07.indd. 2005;109-27.

11. Merskey H, Bogduk N. Classification of Chronic Pain. International Association for the Study of Pain: $2^{\text {nd }}$ ed. Seattle. 1994;3-4.

12. Clifford JW. What is this thing called pain? J Clin Investigation. 2010;120(11):3742-4.

13. Jennifer NS, Tricia K, Janet Y, Navreet G, Bonnie S. Systematic review of the psychometric properties, interpretability and feasibility of self-report pain intensity measures for use in clinical trials in children and adolescents. Pain. 2006;125(1):143-57.

14. Varni JW, Thompson KL, Hanson V. The Varni/Thompson Pediatric Pain Questionnaire. I. Chronic musculoskeletal pain in juvenile rheumatoid arthritis. Pain; 1987;28(1):27-38.

15. Common Laboratory Animals. In: Ghosh MN. Fundamentals of Experimental Pharmacology. $6^{\text {th }} \mathrm{Ed}$. Kolkata, Ghosh SK and Others. 2015:1-13.

16. Central Analgesic Activity In: Vogel HG, Vogel WH, editors. Drug discovery and evaluation: pharmacological assays. Springer Science and Business Media. $3^{\text {rd }}$ Ed. Newyork: Springer-Verlag Berlin Heidelberg. 2008:984-1030.

17. Eddy NB, Leimbach D. Synthetic analgesics. II. Dithienyl butenyl-and dithienyl butylamines. J Pharmacol Exp Ther. 1953;107(3):385-93.

18. Tambe DA, Chaudhari TB, Chaudhari S. Analgesic activity of Caralluma adscendens roxb. (Aerial parts). Int J Pharm Res Dev. 2010;7:10-4.

19. Eddy NB, Leimbach D. Synthetic analgesics. II. Dithienyl butenyl-and dithienyl butylamines. J Pharmacol Exp Ther. 1953;107(3):385-93.

20. Nikajoo LT. Analgesic activity of aqueous and alcohol root extracts of Pergularia daemia (forsk.) chiov. Int J Pharm Sci. 2009;1(1):33-7.

21. Bhutia YD, Vijayaraghavan R, Pathak U. Analgesic and anti-inflammatory activity of amifostine, DRDE07 , and their analogs, in mice. Indian J pharmacology. 2010;42(1):17. 
22. Shanmugasundaram P, Venkataraman S. Antinociceptive activity of Hygrophila auriculata (Schum) Heine. Afr J Traditional Complementary Alternative med. 2006;2(1):62-9.

23. Central Analgesic Activity In: Vogel HG, Vogel WH, editors. Drug discovery and evaluation: pharmacological assays. Springer Science \& Business Media. $3^{\text {rd }}$ Ed. Newyork: Springer-Verlag Berlin Heidelberg. 2008:984-1030.

24. Hemamalini K, Om Prasad Naik K, Ashok P. Antiinflammatory and analgesic effect of methanolic extract of Anogeissus acuminate leaf. Int J Pharm Biomed Res. 2010;1(3):98-101.

25. Hunskaar S, Hole $\mathrm{K}$. The formalin test in mice: dissociation between inflammatory and noninflammatory pain. Pain. 1987;30(1):103-14.
26. Gondi S, Kummara M. Preclinical screening of a novel compound, 2-chlorothiophene for analgesic activity in swiss albino mice. Int $\mathbf{J}$ Basic Clin Pharmacol. 2018;7(7):1421.

27. Gondi S, Kummara M. Preclinical screening of a novel compound, 4-chlorothiophene for analgesic activity in swiss albino mice. Int $\mathbf{J}$ Basic Clin Pharmacol. 2018;7(7):1421.

Cite this article as: Ganugapeta N, Reddythala SSK. Screening of novel 2-4 methylphenylimino-3carboxamide substituted thiophene compound for central analgesic activity. Int J Basic Clin Pharmacol 2021;10:238-44. 